\title{
MONITORING OF THE ABSORBED DOSE OF RATES RADIATION IN THE RURAL AREAS
}

\section{Biljana Vučković ${ }^{1 *}$, Smilja Čanaćević ${ }^{1}$}

${ }^{1}$ Faculty of Natural Sciences and Mathematics, University of Priština, Kosovska Mitrovica, Serbia.

\begin{abstract}
Man is constantly exposed to radiation from the radionuclides from the environment. This study presents the results of measuring the absorbed dose rates of natural ionizing radiation in rural areas in the municipality of Štrpce, in southern part of Kosovo and Metohija. The measurements were conducted in 20 houses in two cycles: when rooms were not heated, and when they were warmed up in the same season. Ten observed houses were with basement rooms, and ten others were without basements. The absorbed dose rate of radiation
\end{abstract}

was measured by Gaiger-Miller's counter DR-M3. Mean value of the measured absorbed dose rate was $1.93 \mu \mathrm{Gy} / \mathrm{h}$ - in the first cycle and $1.47 \mu \mathrm{Gy} / \mathrm{h}$ in the second cycle. At the same time the values of the absorbed dose of radiation in the environmental were measured, and obtained values were $1.77 \mu \mathrm{Gy} / \mathrm{h}$ and $1.33 \mu \mathrm{Gy} / \mathrm{h}$, respectively. Relations between absorbed dose in the premises and in the environment were $\mathbf{1 . 0 9}$ in first cycle, and 1.1 in the second cycle of measurements.

Key words: intensity of absorbed dose, GM counter, unheated and heated rooms, inside of houses, outside of houses.

\section{INTRODUCTION}

Unlike a number of other harmful effects of physical agents to which humans are exposed, ionizing radiation is one of the most dangerous. Radiation is carcinogenic and causes damage to genes (Dainiak, 1997), (Janković-Mandić et al., 2007), (Turner, 2007), (Župunski et al., 2008). The most significant sources of ionizing radiation in the environment are terrestrial radionuclides whose half-life is comparable with the age of the Earth $\left(10^{5}-10^{16}\right.$ years) (Abdel-Rahman et al., 2010), (Draganić, 1996), (Vučina et al., 2005). Another important source of natural radiation is cosmic radiation. Primary galactic cosmic radiation is of the solar origin, and consists of charged particles of very high energy (Rajković, 2001). It rarely reaches the earth's surface, but it creates secondary cosmic radiation and radionuclides (Draganić, 1996), (Veriš et al., 2009). A total cosmic radiation on earth has a greater impact at the poles than at the equator, due to a stronger electromagnetic impact that turns radiation. Also with increasing altitude radiation increases due to diluted air, so that at 4000-12000 m altitude radiation is higher as about $25 \%$ (Crnogorac et al., 2012).

In addition to natural sources of ionizing radiation, in the second part of the 20th century anthropogenic (artificial) sources become a significant problem which presents $5 \%$ of total radiation on Earth (Crnogorac et al., 2012).

Investigation of external exposure in the environment is done by measuring the absorbed dose rate of radiation. In addition to the above mention reason the dose of radiation to which man is exposed depends on food and water that man enters into body (UNSCEAR, 2000). The received dose can be three to four times higher in the mountains than on the surface (Rajković, 2001), (UNSCEAR, 1993). The average worldwide value of the absorbed dose rate is 59 $\mathrm{nGy} / \mathrm{h}$, with a variation in the range from $18 \mathrm{nGy} / \mathrm{h}$ to $93 \mathrm{nGy} / \mathrm{h}$ (UNSCEAR, 2000). When the annual radiation exposure is estimated time spent inside should be also considered, since the building materials contain natural radionuclides. The mean value of the absorbed dose rate of radiation in an enclosed space at a global level is $84 \mathrm{nGy} / \mathrm{h}$, with a variation in the range from $20 \mathrm{nGy} / \mathrm{h}$ to $200 \mathrm{nGy} / \mathrm{h}$ (UNSCEAR, 2000).

The aim of this study was to measure the absorbed dose rate of radiation in rural areas, inside and outside of houses, in the municipality of Strpce. Since there are no measured values in this area, the results of this monitoring can be a basis for further research. 


\section{INVESTIGATING AREA}

Measurement of the absorbed dose rate was conducted in 20 houses in the area of the municipality of Štrpce $\left(42^{\circ} 14^{\prime} \mathrm{N}, 21^{\circ} 01^{\prime} \mathrm{E}\right)$, which has around 13.600 citizens. Strpce is situated at an altitude of $974 \mathrm{~m}$, fig. 1. The municipality is located on Sar Mountain, whose geological structure is characterized by igneous and metamorphic rocks, primarily diabase (Sehić, 2007).

\section{MATERIALS AND METHODS}

The absorbed dose rate of radiation in the municipality of Štrpce was measured by GeigerMiller's counter DR-M3. Its interface is very simple and easy for use. During measurements the device was located at a height of $1 \mathrm{~m}$ from the floor (on the premises) or on the ground (in the open). GM counter operation is based on the ionization of the gas by passage of radiation. The ionization is considerably amplified by means of the avalanche effect to produce an easily measured detection - pulse. The pulses are counted at certain intervals of time and on basis of that information absorbed dose rate was calculated.

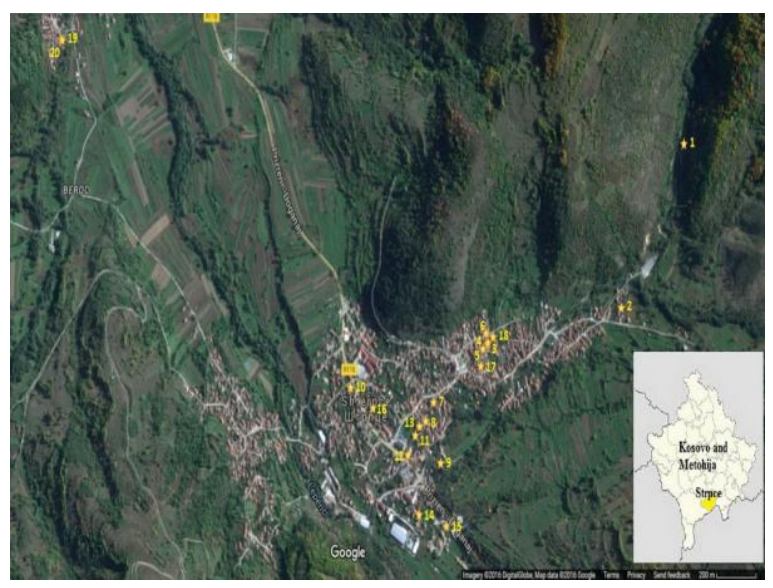

Fig. 1. Map of measuring places in Štrpce.

Table 1. The absorbed dose rates (D) measured inside and outside of homes.

\begin{tabular}{|c|c|c|c|c|c|}
\hline & \multirow{3}{*}{ No } & \multicolumn{4}{|c|}{ Intensity of absorbed doses in the air $(\mu \mathrm{Gy} / \mathrm{h})$} \\
\hline & & \multicolumn{2}{|c|}{$\begin{array}{l}\text { The first cycle of measurements } \\
\text { (unheated rooms) }\end{array}$} & \multicolumn{2}{|c|}{$\begin{array}{l}\text { The second cycle of measurements } \\
\text { (heated rooms) }\end{array}$} \\
\hline & & Inside & Outside & Inside & Outside \\
\hline \multirow{10}{*}{$\begin{array}{l}\text { Houses } \\
\text { without } \\
\text { basement }\end{array}$} & 1. & 1 & 1 & 0.8 & 0.7 \\
\hline & 2. & 0.7 & 0.7 & 0.5 & 0.7 \\
\hline & 3. & 2 & 2 & 0.8 & 0.8 \\
\hline & 4. & 2 & 1.5 & 1 & 1 \\
\hline & 5. & 0.7 & 0.8 & 1 & 1 \\
\hline & 6. & 2 & 2 & 0.7 & 0.7 \\
\hline & 7. & 1 & 1 & 2 & 1.5 \\
\hline & 8. & 2 & 2 & 0.7 & 0.6 \\
\hline & 9. & 1.5 & 1.5 & 0.5 & 0.7 \\
\hline & 10. & 1.5 & 1 & 0.8 & 0.6 \\
\hline \multirow{10}{*}{$\begin{array}{l}\text { Houses } \\
\text { with } \\
\text { basement }\end{array}$} & 11. & 1.5 & 1.5 & 6 & 5 \\
\hline & 12. & 2 & 2 & 5 & 4 \\
\hline & 13. & 1.5 & 1.5 & 2 & 2 \\
\hline & 14. & 2 & 2 & 0.6 & 0.5 \\
\hline & 15. & 2 & 2 & 0.7 & 0.7 \\
\hline & 16. & 2 & 2 & 0.7 & 0.6 \\
\hline & 17. & 1.5 & 1.5 & 3 & 3 \\
\hline & 18. & 10 & 8 & 1 & 1 \\
\hline & 19. & 0.8 & 0.7 & 0.8 & 0.9 \\
\hline & 20. & 1 & 0.7 & 0.8 & 0.7 \\
\hline
\end{tabular}

Table 2. Descriptive statistic of measured values of absorbed dose rates.

\begin{tabular}{|l|l|l|l|l|l|l|l|l|l|}
\hline \multicolumn{2}{|c|}{} & No & $\begin{array}{l}\text { Min } \\
(\mu \mathrm{Gy} / \mathrm{h})\end{array}$ & $\begin{array}{l}\text { Max } \\
(\mu \mathrm{Gy} / \mathrm{h})\end{array}$ & SD & $\begin{array}{l}\text { Median } \\
(\mu \mathrm{Gy} / \mathrm{h})\end{array}$ & $\begin{array}{l}\text { Mean } \\
(\mu \mathrm{Gy} / \mathrm{h})\end{array}$ & $\begin{array}{l}\text { GM } \\
(\mu \mathrm{Gy} / \mathrm{h})\end{array}$ & GSD \\
\hline \multirow{2}{*}{$\begin{array}{l}\text { First } \\
\text { cycle }\end{array}$} & inside & 20 & 0.7 & 10 & 1.96 & 1.5 & 1.935 & 1.753 & 2.086 \\
\cline { 2 - 10 } & outside & 20 & 0.7 & 8 & 1.55 & 1.5 & 1.770 & 1.619 & 1.990 \\
\hline \multirow{2}{*}{$\begin{array}{l}\text { Second } \\
\text { cycle }\end{array}$} & inside & 20 & 0.5 & 6 & 1.52 & 0.8 & 1.470 & 1.276 & 2.219 \\
\cline { 2 - 10 } & outside & 20 & 0.5 & 5 & 1.24 & 0.7 & 1.335 & 1.207 & 2.081 \\
\hline
\end{tabular}

SD-standard deviation, GM-geometric mean, GSD-geometric standard deviation. 


\section{RESULTS AND DISCUSSION}

The study included 20 houses - 10 without basements and 10 with basements. Results are presented in Table 1. These houses were mostly built in the second part of 20th century with the common materials - bricks and concrete. All measurements were taken in the same season - autumn, in the ground floor rooms with concrete floors, as follows: when the rooms are not heated, and then when they are heated. At the same time the values of the absorbed dose rates were measured in the environment.

In the first cycle of measurements when the rooms were not heated, the values of the dose rates were same inside and outside of houses at 14 measuring places. In five measuring places values of doses were lower outside the house. Only at one measuring place measured dose from outside was higher than the dose from inside of the house. The same measured values of the dose suggest that additional sources of radionuclides in the house do not exist. Also in warmer days the room is ventilated more frequently, which causes the equalization of the concentration of radionuclides.

In the second cycle of measurements, when the rooms were heated, at ten locations higher doses were measured inside than outside, which could be the result of lower ventilation in cold period. At eight locations measured values of the dose rates were same in both cases - inside and outside of houses. The higher doses outside the house were measured only at three locations.

From results obtained in this study it could be seen that there are three extreme values. In the first cycle of measurement one of extreme values was at measuring place 18: $10 \mu \mathrm{Gy} / \mathrm{h}$ - inside of house, and $8 \mu \mathrm{Gy} / \mathrm{h}$ outside of house. Reason of that could be sudden influx of radionuclides due to the increased air turbulence. But when the room was heated at this measuring place, both measured values were not extreme. In the second cycle of measurements slightly higher values of 6 and $5 \mu \mathrm{Gy} / \mathrm{h}$ were measured in the houses at the measuring places 11 and 12, respectively. Also, at these measuring places the higher value of external dose $(5 \mu \mathrm{Gy} / \mathrm{h}$ and $4 \mu \mathrm{Gy} / \mathrm{h})$ was measured. This all leads to the conclusion that there is increased concentration of radionuclides due to the air flow, as well as increased penetration into the interior, through cracks in the walls or through the cavity around the window.
Table 2 presents the descriptive statistic of these measured values of the absorbed dose rates. The values were obtained using the KS test.

Mean values of the absorbed dose rate from outside of houses are $1.77 \mu \mathrm{Gy} / \mathrm{h}$ (first cycle) and 1.33 $\mu \mathrm{Gy} / \mathrm{h}$ (second cycle). Relations between the mean values of the absorbed dose inside and outside of houses totaled to 1.09 in the first cycle, and 1.1 in the second cycle of measurement, which corresponds to the global average (interval from 0.6 to 2.3) (Crnogorac et al., 2012). From these mean values of the absorbed dose rates can be seen that this area is characterized by increased radioactivity of air. It is influenced by its environment, primarily the altitude, weather conditions and the morphology of the soil.

The fig. 2 and 3 present interdependence of the measured values of the dose rates inside of houses. If the images are compared it can be seen that a greater range of measured values was noted in houses without basements. This leads to the conclusion that the existence of the basement reduced the direct penetration of radionuclides from the soil to the interior of the building.

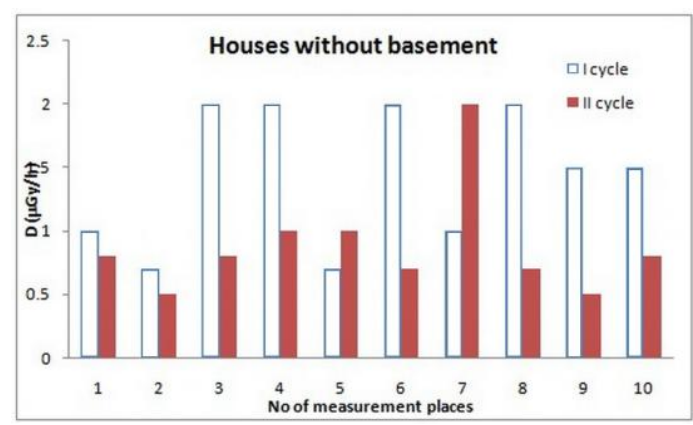

Fig. 2. The measured values of the absorbed dose rate (D) in houses without basements

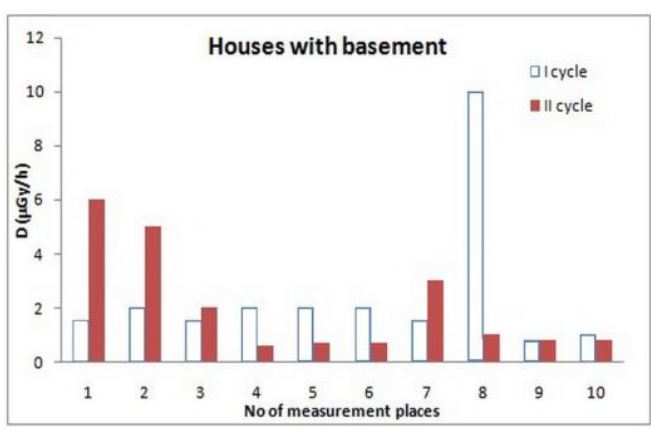

Fig. 3. The measured values of the absorbed dose rate (D) in houses with basements

Results of measurement subjected to t-test showed that two-tailed $\mathrm{P}$ values in three different cases equal: (1) 0.2699 - when rooms in all houses were without heating, (2) 0.0817 - when rooms in all houses were warmed, and (3) 0.7303 - when rooms in 10 houses 
with basements were without heating. By conventional criteria, these differences are considered not to be statistically significant. Results of measurement subjected to t-test showed that two-tailed $\mathrm{P}$ value equals 0.0208 for 10 houses without basements, where rooms were without heating and when heated. By conventional criteria, this difference is considered to be statistically significant.

\section{CONCLUSION}

In this study, monitoring of the absorbed dose rates was conducted in the area of the municipality of Strpce in 20 houses, (10 houses with basements and 10 without basements). GM counter DR-M3 was used to measure the value of the absorbed dose rates of radiation inside and outside, when the rooms were not heated (first cycle) and when they were heated (second cycle). From the graph of their interdependence can be concluded that the higher the dose rates were measured in houses without basements. This leads to the conclusion that the existence of the basement reduced the direct penetration of radionuclides from the soil into the interior of a house.

The results also show that the territory of the municipality of Štrpce is characterized by high absorbed dose rates inside $(1.93 \mu \mathrm{Gy} / \mathrm{h}$ and 1.47 $\mu \mathrm{Gy} / \mathrm{h})$ and outside of houses $(1.77 \mu \mathrm{Gy} / \mathrm{h}$ and 1.33 $\mu \mathrm{Gy} / \mathrm{h})$. The mean values of the absorbed dose inside and outside of homes totaled to 1.09 in first cycle, and 1.1 in the second cycle of measurement, which corresponds to the global average. This may be a result of higher altitudes, where Štrpce lies on one hand, and the geological structure of the soil on the other hand. Large fluctuations of air radioactivity can be caused by a number of other meteorological conditions (temperature, humidity, pressure, velocity air mixture).

\section{ACKNOWLEDGEMENTS}

The authors are grateful to the owners of houses in which these measurements e carried out.

\section{REFERENCES}

Abdel-Rahman, W., \& Podgorsak, E. B. 2010. Energy transfer and energy absorption in photon interactions with matter revisited: A step-by-step illustrated approach. Radiat. Phys. Chem., 79, pp. 552-566.

Crnogorac, Č., \& Spahić, M. 2012. Basics of ecology.Banja Luka: ARTPRINT. on Serbian.

Dainiak, N. 1997. Mechanisms of radiation injury: Impact of molecular medicine. Stem cells, 15, pp. 15.

Draganić, I. 1996. Through the world of radiation and radioactivity.Beograd: Geoinstitut; Beograd: Zavod za izdavanje udžbenika. (on Serbian).

Janković-Mandić, L., \& Dragović, S. 2007. Terrestrial radiation risk due to exposure to the population of cities Serbia. .In: 'Terrestrial radiation risk due to exposure to the population of cities Serbia', XXIV Symposium DZZSCG, Zlatibor. , pp. 63-67 on Serbian.

Rajković, M. B. 2001. Depleted uranium I: Uranium, radioactivity and legal regulations. Hem. Ind., 55(4), pp. 167-182. (on Serbian).

Sehić, D. 2007. Geological atlas of Serbia-for schools and home.Belgrade: Monde Neuf.. (on Serbian).

Turner, E. J. 2007. Atoms, Radiation, and Radiation Protection.Weinheim: WILEY-VCH Verlag GmbH \& Co. KGaA.

-United Nations Scientific Committee on the Effects of Atomic Radiation, UNSCEAR. 1993. United Nations Sources and Effects of Ionizing Radiation. Report to the General Assembly, with Scientific Annexes.New York: United Nations.

-United Nations Scientific Committee on the Effects of Atomic Radiation, UNSCEAR. 2000. Sources and effects of ionizing radiation. Report to General Assembly, with Scientific Annexes.New York: United Nations.

Veriš, A., Ćetojević, D., Mijatović, D., \& Tramošljika, Lj. 2009. The impact of radiation on the human body. . In: Ist International Conference ECOLOGICAL SAFETY IN POST_MODERN ENVIROMENT, 2009-06-26, Banja Luka, RS,BiH. (on Serbian).

Vučina, J., Orlić, M., \& Vranješ, S. 2006. Radionuclides and ionising radiation. Acta Clinica, 5(1), pp. 9-22. (on Serbian).

Župunski, L., Trobok, M., Gordanić, V., Jokić-Spasić, V., \& Sovilj, P. 2009. The impact of population exposure to natural radionuclides radium at increased risk of developing a tumor by entering the parent nuclide uranium via ingestion or by inhalation. . In: XXV Symposium DZZSCG, Kopaonik., pp. 43-45 (on Serbian).

\footnotetext{
*E-mail: biljana.vuckovic@pr.ac.rs
} 